Revue d'études américaines. American Studies Journal

$1 \mid 2016$

Modernist Revolutions: American Poetry and the

Paradigm of the New

\title{
Fiction Rescues History: Don DeLillo Conference in Paris
}

Paris Diderot University and Paris Sorbonne University, February $18^{\text {th }}$ $20^{\text {th }}, 2016$

Luca Ferrando Battistà, Maud Bougerol, Aliette Ventejoux, Béatrice Pire and Sarah Boulet

\section{OpenEdition}

Electronic version

URL: https://journals.openedition.org/transatlantica/8181

DOI: 10.4000/transatlantica.8181

ISSN: $1765-2766$

Publisher

Association française d'Etudes Américaines (AFEA)

Electronic reference

Luca Ferrando Battistà, Maud Bougerol, Aliette Ventejoux, Béatrice Pire and Sarah Boulet, "Fiction Rescues History: Don DeLillo Conference in Paris", Transatlantica [Online], 1 | 2016, Online since 04 February 2017, connection on 01 February 2023. URL: http://journals.openedition.org/transatlantica/ 8181 ; DOI: https://doi.org/10.4000/transatlantica.8181

This text was automatically generated on 1 February 2023

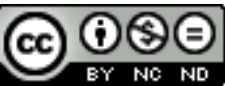

Creative Commons - Attribution-NonCommercial-NoDerivatives 4.0 International - CC BY-NC-ND 4.0 https://creativecommons.org/licenses/by-nc-nd/4.0/ 


\title{
Fiction Rescues History: Don DeLillo Conference in Paris
}

Paris Diderot University and Paris Sorbonne University, February $18^{\text {th }}$ $20^{\text {th }}, 2016$

\author{
Luca Ferrando Battistà, Maud Bougerol, Aliette Ventejoux, Béatrice Pire \\ and Sarah Boulet
}

1 The Don DeLillo conference which took place in Paris from Thursday, February $18^{\text {th }}$ to Saturday, February $20^{\text {th }}, 2016$ was a major event graced by the presence of the author himself and prestigious DeLillo scholars, and attended by a numerous audience. It was hosted by Paris Diderot University and Paris Sorbonne University, and organized by Antoine Cazé, Karim Daanoune, Jean-Yves Pellegrin and Anne-Laure Tissut.

2 In the call for papers, the organizers remarked how "Don DeLillo unearths the mechanisms of history by securely anchoring his fiction in historical reality" and how "the stuff of history is constitutive of his fiction". The numerous Don DeLillo scholars who attended did indeed try to "focus on the shaping power of history in DeLillo's work."

N Fiday evening, the performance of DeLillo's play The Word for Snow at the Cite internationale, attended by the author, added a welcome counterpoint to the conference.

4 Although the following account does not cover all the workshops of the conference, it nevertheless gives an idea of the areas covered

\section{Thursday, February 18}

5 The conference started with a speech given by Don DeLillo, a reflection upon time and writing. From the kid from the Bronx that he used to be till the last, recently published novel Zero K., DeLillo's speech rotated on some key concepts: Time, How deep is time? how far down in the life of matter do we have to go before we understand what time is?. The Image, both seen as the visual quality of writing and the frequent use of photography and 
pictures in his novels; the Word, the beauty of the alphabet in its inner plasticity, the possibility of words to describe in their physiognomy alone just what the writer means; the Room, the power of those spaces and of the men enclosed in them.

The speech took shape around the writer's room and what gradually comes into sight, from his notebook to the typewriter (Do I remember the novel? I remember the typewriter): every object has a light that can retrospectively illuminate all the work required to write a novel and that may often be forgotten.

The speech ended after the author answered some questions raised by the public as to the relationship between the novel and history, opening onto a discussion on the power of narrative to give history a meaning and, somehow, to rescue it.

\section{Workshop 1: Violence and History (Moderator. L. Barrett)}

In the first workshop, three papers were presented and they all concerned time to some extent.

Paolo Simonetti (Università di Roma La Sapienza): “History of Futures Past: Don DeLillo's Cosmopolis and Thomas Pynchon's Bleeding Edge".

Paolo Simonetti introduced a comparison between Cosmopolis and Thomas Pynchon's Bleeding Edge. Both novels were read in the light of Melville's Confidence Man since, as Simonetti argued, "Melville systematically challenges the chronological time and the rational transparency of mechanical or organic time that foster ideological progress." Cosmopolis and Bleeding Edge deal with time in a similar way, more specifically the cosmological time of such a cosmopolis as New York and its relation with technology. The temporal dislocation of the main characters, the obsolescence of the city and the narrative fragmentation recall Derrida's differAnce. According to Simonetti DeLillo and Pynchon's characters live in a Derridean "futur antérieur", "a future that has not come yet and so it has not been determined, but which retrospectively defines that past which will make it possible." Living in the "futur antérieur" is tricky because it is possible to change it and, in Simonetti's point of view it is through this concept of time that fiction can rescue history.

Isabel Lane (Yale University): “Representing the Arms: Time and By-product in the Russian-American 1990s"

10 The manipulation of time performed by the nuclear weapon and waste was the main theme of the second paper, presented by Isabel Lane. She also quoted Derrida to describe the cold war particular timing status, continuously dealing with the "never experienced". Comparing DeLillo's Underworld and Vladimir Sorokin's Blue Lard Lane argued that "the nuclear has altered the time" and space of the novel. She also underlined the complex relationship between the bomb and its nuclear by-product which are linked in a cycle. In Underworld the bomb blast allows the final destruction of the waste, while in Blue Lard it is instead the by-product that travels through time and makes the explosion possible. 
Matt Kavanagh (Okanagan College): "American Bloodline: on the Origins of Libra"

11 The first day ended with Matt Kavanagh's paper which first brought to light a sixteen pages' film script written by DeLillo while working on the Rolling Stone essay "American Blood." The script tells the story of a young woman who coming back to her parent's house finds out she has a half-brother who was given for adoption at birth. The search for her brother becomes a quest that defines her own identity, and ends when she finds him in Mexico City involved in an American Cuban conspiracy to kill Kennedy. What is interesting according to Kavanagh is the singular perspective from which the conspiracy is looked upon as it is approached only laterally in the script, completely leaving out the real Lee Harvey Oswald.

\section{Friday, February 19}

\section{Workshop 2: The Suspension of History (Moderator J. Zubeck)}

\section{Nicholas Manning (Université Paris-Sorbonne, France): "The Uses of Boredom. Don DeLillo and the Emotional Disengagement with History"}

Nicholas Manning explores boredom as "a shield from deeper feelings", as Don DeLillo put it in Players (1977). According to him, the response of De Lillo's characters when faced with threatening historical affects is a form of despondency, boredom becoming a defence mechanism against the endangerment of the self. Consequently, boredom defines the self by "keeping man from engaging with the world". Manning suggests that for characters like Pammy, it even becomes an act of rebellion, because it defends and frees the self from the restrictions of self-definition. He quotes Nietzsche and his conception of boredom as the shield and what is shielded against, which leads to a paradoxical conception of boredom: a barrier both against the disappointment of the desires being met and the fulfilment of those desires. According to Manning, boredom thus appears as a disconnection from community and history, the collective becoming of this community. Boredom in Don De Lillo's novels works alongside the difficulty of constructing a coherent narrative of history. Things change but the self does not change with them, so boredom allows the experience of time and meaning within the self. According to Manning, we, as readers, are similarly absorbed. The characters also seek boredom as a form of attention. The quest to forge a personal history is linked to the notion of attention in Don DeLillo's work because the act of making sense and attention are on the same hermeneutic plane. The characters are absorbed, in a state of suspension, which paves the way for the historic real. According to Manning, the self is a historical being, so it is accepted that it cannot be constructed outside of time. Boredom, however, is the disturbing possibility that it can.

\section{Mark Osteen (Loyola University Maryland, USA): “The Living and the Undead: Don} DeLillo's Late Style"

13 According to Mark Osteen, Don De Lillo's "lateness" can be defined by "crafting moments of being, motionless and static". The author is fascinated with death, loss and mourning. In his late works, he explores lateness in themes and characters rather than style, through experiences of suspended life. His late works focus on "undeath" rather than death. The characters occupy non-normative bodily and mental spaces, in 
particular in Falling Man and White Noise. Don DeLillo thus frames the posttraumatic state of his characters. In Love-Lies-Bleeding, Alex's condition represents that of the other characters: they are all in a form of vegetative state, using his body as a blank canvas on which they can project everything they want. They feed on his essence, which makes more striking his emotional absence. In Point Omega, the shadow of the "undeath" of Mrs. Bates, through 24 Hours Psycho, looms over the plot, even Jessie is more present after her disappearance. In his most recent fiction, "The Starveling", the characters live at pause, in a state suspended between the living and the dead. These suspended figures represent "our liminal age, dangling between two worlds".

\section{Linda Kauffman (University of Maryland, USA): “History and Slow Time: Don DeLillo's Point Omega"}

Linda Kauffman explores historical consciousness in Point Omega, which is framed by portraits of two serial killers. In the first part, Gordon cauterises a classic with $24 \mathrm{Hour}$ Psycho, through serial repetition: we are shuttered into the sensations of the character who watches the film. The second part deals with serial repetition through the figure of Elster, who excels in linguistics and used his expertise to convince the American people of the validity of his actions. 24 Hour Psycho and The Fog of War - a film in which each frame is "seared in the World's collective memory" - converge through history and slow time: fiction rescues history. Through the transactional nature of new technologies, the spectators become active, "masters of remediation". The subject of war remains an open wound in the American consciousness. According to Kauffman, there is more blindness than insight in the characters of Point Omega. As with McNamara and Rumsfeld, DeLillo's serial killer goes free.

\section{Plenary Lecture by Michael Naas (DePaul University, USA): “DeLillo's contraband”}

Michael Naas explores what has made Don DeLillo a "true American original": his ingenious exploitation of literary contraband and of literature as contraband. Don DeLillo "smuggles" his unique narrative technique into prose through a "contrabanded relationship" between words and things. Beyond the use of items of contraband such as knives and firearms in his stories, Don DeLillo focuses on secret organizations which "circulate in a contraband discourse and secret codes" such as the mafia, religious groups and cults, sometimes indistinguishable from the organizations they are supposed to combat. According to Michael Naas, "it's never band against contraband, but always one underground against another".

16 Michael Naas explains that Don De Lillo's novels deal with language in a way that covert communications one thinks one can control actually dwell just below the surface. This leads to the emergence of an underground language in which subtleties and ambiguities aim at simplicity to create a contraband "in and of language". Don De Lillo's mode of writing is a form of counterlanguage supplying a web of contraband narratives in which incongruous elements are "smuggled in", but meant to be detected, while trying to pass undetected. According to Michael Naas, there is a back and forth movement between "band and contraband", "narrative and counternarrative", triggered by shifts in language and changes in register. The "contraband effect", which is the emergence of a new "track" in the narrative, takes place as words and things become confused, allowing the reader to see the movement between the two "bands" to 
the point where they intersect without ever merging or being absorbed because "one is never the dialectical counterpart of the other, but irritates it".

Michael Naas uses Don DeLillo's “organic shrapnel” to explain how, in the case of 9/11, the images of the event interrupt, infect and ultimately contraband the event itself. In the same mode, the codes and secret languages of ideology, ubiquitous in his prose, "enter and become" the reader, the inorganic revealing itself as something different from what we thought it was. According to Michael Naas, literature "smuggles" within us little bits of language, fragments, words that Don DeLillo has signed, "infected", periods and commas that are like little bits of shrapnel delaying the identification of the subject.

According to Michael Naas, the contraband is what makes the band possible.

\title{
Excerpts from Workshop 3: The Refuse of History (moderator C. Davedon) and Workshop 5: Inside and Outside History (Moderator. L. Kaufman)
}

\author{
Aleksandra Vukotic (University of Belgrad, Serbia): "A Second Chance for the \\ Anathematised: (Re)Entering the Narrative"
}

Aleksandra Vukotic focuses on a number of characters in DeLillo's fiction, who are desperate to secure their own place in history and who struggle to reclaim the narrative stolen from them. She opposes these characters, unremarkable people who become misfits, to another group made up of important historical or public figures. For the villains, terrorists and other invisible outcasts, violence becomes the ultimate way of entering the system. Analyzing, among others, the example of Lee Harvey Oswald in Libra and Hammad in Falling Man, she explores the opposition that appears in DeLillo's fiction between the margins (with characters under the historical radar) and the center, where one finds important historical figures. She argues that exclusion from society is part of the construction of DeLillo's villains. As a consequence, they try to rewrite the narrative that was stolen from them, while at the same time fighting for visibility rather than trying to change the system. Vukotic argues that the stories of DeLillo's misfits are lost to history, and shows how his novels relate the importance of understanding evil rather than stigmatizing it. She emphasizes the role of the media and celebrity culture in the fight for visibility, as well as the connection between the lack of media ethics and violence. She concludes her paper by asking if DeLillo's novels show sympathy for these outcasts, stressing that the author rather tries to understand the villains in a wider historical context. According to her, fiction rescues history by granting the villains a chance to reclaim their stories and see their humanity restored. Thus she reminds us of the importance of the voice of fiction to look at the stories of misfits, and grant them a right to their own narrative.

\section{Rebecca Harding (University of Sussex, England): "'To float this image free of history': Ahistorical Forms in Mao II"}

Rebecca Harding interrogates the relationship between image and text and focuses on the form and complex status of the photographed face. She argues that photography plays an important and intriguing role in DeLillo's fiction and that the author's interest lies not only in the medium of photography, but also in the possible exchange of 
meaning between people and photographs. In order to illustrate this questioning regarding the nature of the photographed face as well as the relationship between image and text, she focuses first on an interview given by DeLillo about his writing process, in which he stresses the importance, for him, of a photograph of Borges. Studying the personal and evocative engagement of the writer with the photograph, she goes on to analyze DeLillo's approach to writing, the visual specificity of the photographed faces that appear in his fiction, more particularly that of Mao in Mao II. She analysis Warhol's screen prints as opposed to Betty Grable's image, an icon prior to the television age and with a direct connection to the passage of history itself, whereas Warhol's icons are equivalent and can be exchanged. Thanks to these examples, she lays stress on the possibilities of the image to express what language cannot.

Luca Ferrando Battistà (Université Paris Diderot, France): “'The Room a World'. The room: narrative device and space of progressing in Great Jones Street, Libra, The Body Artist, Falling Man and Cosmopolis"

Luca Ferrando Battistà focuses on two aspects of the idea of the room in DeLillo's work: the fact that it has a double meaning, and then its metropolitan nature. First, the room is both a physical and a mental space. It allows a new temporality to emerge, utterly different from that of the outer world. Taking the examples of Great Jones Street and The Body Artist, Battistà underlines the difference between two ways of experiencing time: the objective time of history on the one hand, and personal temporality on the other. It is only by going out of the room that the characters can get back to the world's temporality, but exiting the room can be devastating.

Battista also insists on the metropolitan character of the room which, in DeLillo's fiction, is most of the time located in New York. Without this metropolitan quality, the room is altogether isolated from the world and can become a terminal location. The room also functions as a space where the characters can create their counternarratives. Rooms are shown as spaces allowing a transformation, where characters also undergo a change of temporality: time escapes from its boundaries, external time increasingly resembles internal time.

\section{Workshop 4: The Subject of History (Moderator M. Osteen) \\ Laura Barrett (State University New York, USA): “'Living in the third person': Don DeLillo's Uncanny America"}

Laura Barrett explores the concept of home in Don DeLillo's fiction. According to her, "homes are ambiguous signs, haunted by the eerie sounds of technology". The characters move between home and homelessness, safety and exposition. For example, in Americana, the home is "a space that illustrates the uncanniness of the American dream/nightmare". The reality becomes flimsy in the relationship between the uncanny self - another human or something inhuman -, but also between life and death. The intrusion of technology into the homes "destabilizes our understanding of what it is to be human". She takes the example of the telephone, "trope of disindividualization". According to Barrett, the unhomely is built in the fabric of home and thus every space bears a tension between comfort and alienation, particularly in Americana. The themes of death and life explored in the novel echo the liminal spaces 
that characterize the uncanny. The character of David tries to "eradicate his relationship with his country by doing an autobiography without an I, a home without a home". He uses a motel room, a "space of casual connections, defined by transience, to soak the growing uniformity of American culture', which results in the loss of the self. According to Barrett, home is less a place than a point of view, and America is less a country than an image, that of Americana. She concludes by saying that the American dream made "no solace for the truth between the symbols" on the model of the uncanny which appears here as the reenchantment of a world disenchanted by too much information and too little heart.

\section{Aaron Smith (University Françoise Rabelais): "The Consolations and Delusions of Narrative: De Lillo's Narrative Double Bind"}

Aaron Smith explores Don DeLillo's problematic concern for representing the historical. In a double approach of the subject, Don DeLillo exploits paradoxical conceptions of the historical, at times evocative, at times reclusive, sometimes presentoriented and sometimes future-oriented. His narrative structure is often neurotic, mirroring the problematical need for structure in the themes and on the characters' part. According to Smith, there are organic links between narrative composition and historical agency in Don DeLillo's prose. The characters are "on a collision course with a very messy reality", they "fall prey to the delusions of history as a classical narrative or pattern", and they are "betrayed by faith and design". Smith explains that the reluctance to move beyond a linear vision of history leads to a dismal future for the characters. The emergence of counternarratives - alternative narratives, which are nonlinear - creates ambivalence in the prose between opposing narrative modes, notably in Falling Man and Cosmopolis. According to Smith, Don DeLillo undermines in his novels the delusional conception of a historical narrative through combining formalistic and anti-formalistic approaches, a double bind between a goal-oriented and a present-oriented fiction.

\section{Cornelius Collins (Fordham University, USA): “'Checking the Local Papers, Wherever I Happened to Be': Don De Lillo's Research and Rewriting of Contemporary History"}

Cornelius Collins explores Don DeLillo's relationship to history in his novels through his readings and research. As a novelist of globalization and global unrest, Don DeLillo exploits the discrepancy between what happened and his research, creating "a narrative style marked by ambiguity and distance", focused on the margins of history. Through extensive research, Don DeLillo's has shaped his perspective on globalization. However, according to Collins, he creates authorial space - and autonomy - by departing from his source material. Magazines and news reports are crucial to his research because he's intellectually interested in public discourse, but literary and rhetoric arguments, as well as essays on global politics and debates also inform his prose. In his novels, he reflects on terrorism, totalitarianism and resistance. Ambiguity emerges from the text while he first articulates the product of his research, then reinterprets it. According to Collins, his creative expression is marshalled against the destructive forces of capitalism, most notably in Mao II. 


\title{
Workshop 7: Measuring History (Moderator C. Collins)
}

\author{
Mark Tardi (University of Nizwa, Oman): "The Calculus of History: Ratner's Star, \\ Gödel's Incompleteness, and the Vicious Infinite Regret"
}

Mark Tardi focuses on math as a recurring motif in Don DeLillo's Ratner's Star in which a child math prodigy is tasked with deciphering what is thought to be a message from space. He links the text with Gödel's Incompleteness, a theorem that is a paradox. According to Tardi, the language of mathematics is poetic because theories are sometimes so abstract that they cannot be written down. All through Ratner's Star, the mathematical and the dynamic sublime are paired, creating a conflation of both. The emergence of mysticism in the text makes the scientific elements seem more and more irrational. There's a phenomenon of simultaneous expansion and contraction throughout the novel as Don DeLillo contracts words and names in increasingly smaller parts. Don DeLillo's discourse on technology creating social regression echoes with mathematics, in which the consequences of the insights of the research are usually unknown at first. However, according to Tardi, regression doesn't have to be negative, it is natural, a source of civilization that forces us to revert back to ancient sources.

\section{Collin Meissner (University of Notre Dame, USA): “'All that howling space': Fiction as History in Don De Lillo's Late Novels" Read by Karin Daanoune}

Collin Meissner explores Don DeLillo's concern with words and images that we can use to make sense of attacks such as $9 / 11$. How we can move forward as a society depends on the tension between reality and fiction. According to Meissner, both history and how we have come to understand it frame Don DeLillo's novels, notably in Point Omega. The language is "stretched to the breaking points", the author creating gaps between what the characters say and what they mean, or between what they mean and what other people understand. In Don DeLillo's novels, as terror thrives in a binary paradox, "the absence of knowledge is filled by a narrative". According to Meissner, "the macronarratives of our moments embed themselves in our conscience to provide answers to questions we haven't asked yet". Don DeLillo's narrative structure "moves in and out of patterns similar to PTSD", which results for the reader and the characters in destabilisation, confrontation and finally escape. The reader is required to reconstruct a "mosaic of meanings" which results either in sensory overload - in Falling Man - or in sensory underload - in Point Omega -. According to Meissner, this process works towards exhaustion because in the end the novels reach a destination where the fictional/real point has ended, a form of "introversion" to quote Teilhard de Chardin.

\section{Jacqueline Zubeck (College of Mount Saint Vincent, USA): “The Word for Snow and the Consequences of History"}

Jacqueline Zubeck explores the conjunction of time and space in The Word for Snow. By using Bakhtin's theories on space and time, she demonstrates how time becomes artistically visible in Don DeLillo's work. The author visualizes future events as well as their impact on human consciousness. The Word for Snow focuses on the theme of global warming which diminishes the attention given to war and terror: it is a disaster for which there could be no cure. According to Zubeck, words make manifest our destructive tendencies: if "time is a lie", it is because of the devaluation of the planet. 
The subsequent loss might make us question reality: if human culture is no more in place, then what will happen to our conception of time? The loss of our sense of space might give way to the loss of our sense of humanity. She also insists on the importance of the performance aspect of the play that might hint at a longing for embodiment: it displays a form of representational uncertainty. The small live audiences reflect the quotidian lives of the new millennium. They are built around the interdependent network of humans and their habitat which mirrors the interpenetration of nature and technology, economics and ecology. Moreover, the play hints at the conflict between reference and knowledge through the loss of reference. According to Zubeck, the artist is the seeker of the wonderful specificity and resonance of language in nature. Through the doomed experience portrayed in the play, the artist gives his perception of closure, which is the experience of meaning.

\title{
Saturday, February 20
}

\author{
Workshop 8: "Writing 9/11: The Seismic Tide of the Event" \\ (Moderator. B. Pire)
}

\section{Angeliki Tseti (University of Athens, Greece): “'Living in a Place of Danger and Rage': the Traumatic Residues of History in Don DeLillo's Post 9/1 1 Short Stories"}

Angeliki Tseti compares and contrasts the writing of Falling Man with short stories published after 9/11, mainly "Baader Meinhof" and "Midnight in Dostoievsky". All, she argues, maintain the writer's preoccupations with technology and the media and paint an image of America seized by fear, violence and melancholia. "Technology is our fate, our faith". Settings are claustrophobic, spaces confined, immersed in emptiness, silence, motionlessness and dematerialization. Reenacting trauma, the characters are devoid of personal detail, evade reality and exhibit anti-social behaviors, stuck as they are in patterns of violation and isolation. Altered by its history America exhibits 'the shadow of another life' where the future is suspended. Living language however is not diminished and remains the necessary tool to combat confusion. But while Falling Man is based on structural fragmentation, broken phrases and ellipsis, the short stories beam in eloquent descriptions, artful expressions and clearly articulated feelings, simultaneously reenacting the traumatic residues of history and showing resistance to it.

\section{Christina Cavedon (University of Bern, Switzerland): "Falling Man and American Culture's Refusal to Historicize its Reaction to 9/11"}

31 Christina Cavedon makes a distinction between DeLillo's oeuvre and the trend that posited American history as starting at Ground Zero. White Noise and Cosmopolis help locate American cultural melancholia, by which Cavedon understands white middle class and white upper class Americans' unwillingness to critically examine the reasons for their malaise, oppose liberal imagination and see the side effects of capitalism. Maintaining such state, she says, precludes a confrontation with myths such as the American dream and its failings. Falling Man, like DeLillo's other pre-9/11 fictions, exhibits this American culture's persisting melancholic texture denied by the interpretation of the event as national trauma. 


\section{Françoise Sammarcelli (University Paris Sorbonne): “Writers and Terrorists at Work - or Decentered Voices in Don DeLillo's Mao II and Falling Man"}

Françoise Sammarcelli concludes this workshop entitled "The seismic tide of 9/11" by discussing the "curious knot that binds novelists and terrorists" and the relation between art and terror in Mao II and Falling Man. Using a terrorist as character in Falling Man contributes to a decentering of narrative that contrasts with Mao II where the action is focalized on the poet and not on the hostage-taker. Françoise Sammarcelli points out other differences between the two novels including Falling Man's marginal reference to writers and powerful emphasis on visual artists. The central figure of the author is displaced in favor of the editor, the Alzheimer patients' writing sessions, the art-critic or the voice of protest, brought by the reference to Shelley's long poem Revolt of Islam and Martin Ridnour.

\section{Q\&A Session on Falling Man}

The event of Saturday afternoon was a question and answer session between the audience and the author during which DeLillo mainly discussed his novel Falling Man with the Agrégation candidates and their teachers.

A first question concerned the recurrent reference to "speaking in tongues" in the play The Word for Snow performed the previous evening.

Don DeLillo answered that what triggered his use of this reference was his fascination for people able to speak in tongues as well as the fact that he had not seen a reference to it in many years. The play was the place to address the matter of a language spoken by a very small number of people. He also explained that he had invented most of the words used in the play by the characters "speaking in tongues."

Afterwards, a long series of questions on the novel Falling Man were put forth, among which a first question about DeLillo's experience of writing the novel.

It took the author several years after the terrorist attacks in New York City before thinking about writing a novel on the subject. Once he had made his decision, it was very clear to him that the book had to go into the towers. It was not to be a novel in which the events and results happen at the periphery of the book. He decided that the book had to be direct, which is why the novel begins with a man leaving the World Trade Center on the day of the attacks. DeLillo also stated having been inspired by photographs of the event and, for instance, having decided to give a personality of its own to the briefcase held by a man leaving the towers in one of them.

Another member of the audience noted the refusal of pathos in the novel and asked the author about the conception of the characters, about the way he approaches them.

DeLillo confessed that he did not know much about the characters before writing them. They developed without notes. He described the process according to which words became things, rooms, streets; with the characters building themselves in a mysterious way, both physically and mentally.

Then, a member of the audience asked whether the event of the 9/11 could have been replaced by another in this novel.

To this, the author responded that what he saw became the book, so that it was this particular event which had made this novel. 
A next question concerning the description of Florence as a black woman was put.

DeLillo argued that her being black was not important. She was one figure among others in the World Trade Center, and she "just happened to be a black woman."

Afterwards, the surprising gesture of the terrorist fastening his seatbelt before the crash was evoked, to which DeLillo answered that the terrorist simply fastens his seatbelt automatically, since he knows that the plane is about to crash, which produces a comical effect.

Another member of the audience noted that there was no judgement passed upon the characters in the novel and wondered how hard it was to write this novel without judging.

DeLillo explained that he had to show no fear of trying to understand.

Then, a following question addressed the importance of including the terrorists' points of view.

DeLillo argued that this was not a novelistic choice, but rather a personal choice, that it was part of not avoiding difficult challenges. Indeed, he needed to face that these men caused this catastrophe. He had to confront this level of difficulty.

A following question focused on what made the author include the character of Martin in the novel.

The author tried to cast a global picture of a family. Then the character just came to mind. He was important to the entire complexion of things, to the dialogue, as a figure from another culture looking at this America.

Afterwards, a member of the audience wondered whether DeLillo's view of language had changed throughout his career.

DeLillo affirmed that when he started writing, he had no particular view of language. He would simply write. It took him four years to write his first novel, and language belonged to the narrative, to the characters themselves. Afterwards he started to write very quickly. Then, from the 1980s onward, and particularly from The Names, which marked a turning point in his writing and conception of language, he took his time and began to think more deeply about language.

Another question concerned whether the author's fiction writing between the terrorist attacks in New York City and the writing of Falling Man was affected by the event, even though it did not address it directly.

The author suggested that it was probably the case for his novel Cosmopolis, in which a sense of destruction is to be found.

Finally, this session ended with DeLillo reading a passage from the novel.

INDEX

Subjects: Actualité de la recherche 
AUTHORS

LUCA FERRANDO BATTISTÀ

Paris-Diderot University

MAUD BOUGEROL

University of Rouen

ALIETTE VENTEJOUX

Paris Sorbonne University

BÉATRICE PIRE

Paris Sorbonne University

SARAH BOULET

University of Rouen 